\author{
Hana Vavř́ková, \\ Department of Education and Adult Education \\ Faculty of Education, University of Ostrava, PhD \\ hana.vavrikova@osu.cz
}

\title{
PEDAGOGICAL FACILITATION FROM VIEW OF UNIVERSITY STUDENTS
}

The professional public has been discussing for a long time the reasons why more than 2/5 of Czech students in bachelor's degree programs are unsuccessful in their first study. The paper outlines the possible causes of this phenomenon, mentions partial factors influencing academic success or failure, and also lists the effects of the phenomenon on the life of individuals and society. Last but not least, this paper deals with pedagogical facilitation, ie interpersonal activity, which could eliminate some of the causes of study failure (low internal motivation, frustration), and which could set a favorable educational environment, and thus increase the study success of university students. As part of the preparation of this paper, its author conducted a survey, the aim of which was to look at partial aspects of study failure and pedagogical facilitation from the perspective of students of two forms (full-time, combined) of bachelor's study programs at the Faculty of Education of the University of Ostrava.

Key words: causes of failure, study failure, low motivation, pedagogical facilitation.

(c) Hana Vavř́ḱková, 2020

○ Київський університет імені Бориса Грінченка, 2020

\section{BASIS OF PEDAGOGICAL}

\section{FACILITATION}

The starting point of the paper was the study failure of students of bachelor's degree programs in the Czech Republic. The topic was chosen because unsuccessfully completed studies at universities have been attracting the attention of university management for a long time (after all, we also deal with the issue at our department), the general public and the Ministry of Education. The fact that this is not a marginal topic is evidenced by the fact that already in 2000 The Ministry of Education, Youth and Sports (MEYS) addressed this issue and saw academic failure as a problem to be addressed. According to Kohoutek (2009) "Study failure is a picture and a consequence of individual differences, which we find not only in the personality of students (for example, in the level and structure of talent, character, interest about learning, in emotion, motivation, harmony or disharmoniousness of personality), but also in the area of their performance at school and in their family upbringing." According to Stiburk and Vlk (2017), the study failure presented here is slowly but steadily growing. Especially in bachelor's degree programs, less than half of the studies started successfully complete. This may be due to the fact that the large increase in the number of students over the last twenty years has brought a new student structure to universities.

These are individuals with significantly different backgrounds, with different levels of life experience, with different forms of previous education, with different, often rather with external expectations and with a relatively lower individual educational need than was typical before 1989. In this context, Matějů (2007) even states that in the Czech Republic the contrast of students from the highest and lowest quintiles of the socio-economic status of families is much more pronounced than in other OECD countries. Universities have greatly increased the capacity of students, but are only slowly adapting the concept of teaching, their approach to students and the support services they offer to students. And according to the above authors (2017), the gap between the needs of current students is widening and the offer of universities. According to the data provided by the Ministry of Education, Youth and Sports, the study failure rate is the highest especially in the first two years of bachelor's study. This may be because these students are just getting acquainted with the higher education system and finding out what the tertiary education system looks like and what their teachers actually want from them. However, it is certainly not without interest that most of the individuals who previously left their university studies later decide to study again, but very often these individuals enter a completely different study program. And about two thirds of these students (Ministry of Education, 2020) will eventually complete a field of university study. And the above-mentioned experts (2017) talk about the fact that the field of study is only one of the factors that affect the success of the study.

\section{INSTITUTIONAL SUPPORT FOR STUDY SUCCESS}

Already in 2000, the Ministry of Education declared its support for the maximum possible permeability between individual types of schools in the field of tertiary education so that even students 
whose initial choice of university studies was incorrect can use their personal potential to increase their level by changing education. your education. According to the Ministry of Education, Youth and Sports (2001, p. 8), universities should reduce the study failure of university students because "study failure is not only uneconomical from the point of view of the state, but also has a negative impact on students who do not complete their education". The failure of university students is evidenced by the fact that the topic has become the main topic of the conference Days of Educational Activities of Universities (2020). In connection with the aforementioned institutional support for academic success, Stiburek and Vlk (2017) list the following measures that could have a positive impact on academic success, at least from a long-term perspective. These measures are: improving access information on the form, content and requirements of study programs and support for applicants to choose a suitable program for them; set up relevant measures in the field of admission procedures (typically adjusting tests and criteria so that they can better predict student success); it is necessary to ensure the collection of detailed data on the progress of students and their use for targeting support measures; Supporting the social integration of students and their integration also has a role to play into school life; and institutions should also ensure the equalization of students' chances, especially by offering various support courses, support for mutual learning between students, pedagogical facilitation and the like, and according to the authors (2017) the current form and content of study programs and rules for study.

\section{ELECTED FACTORS AFFECTING THE SUCCESS OF THE UNIVERSITY STUDY}

It is obvious that a number of factors influence study success or study failure. Veteška (2016) divides the given factors into internal (subjective) or external (objective). Among the external factors, the mentioned author (2016) gives includes, for example: the employer's attitude to the study of his employee, the offer of adult education, legislation or the social situation of an adult student. However, Veteška (2016) also includes the social role of the adult student, his family environment and work background for education in external factors. Factors that influence the academic success of adults and which come from the values and attitudes of students, Veteška (2016) calls subjective factors (internal) and includes the internal motivation of students or their aspirations. With regard to the spatial subsidy of this article, only selected factors influencing the success of university studies will be presented here. The first of the factors mentioned here will be the low level of educational needs. Šed'ová and Novotný (2006) point out that adults in the Czech Republic do not want to be further educated, that they have a low internal motivation to study, and that they do not have an individual educational need. According to Šed'ová and Novotný (2006), she was interested at the turn of the millennium for further education only $11 \%$ of adults. According to Motschnig and Nykl (2011), this may also be the case because many adults are unable to learn and are afraid of their possible academic failure. Another external factor that influences academic success or failure is undoubtedly the process of education itself. It is a very dynamic process that increasingly shifts its attention to the student, whose educational institution no longer perceives as a passive recipient of target information, but asks him to search for the information needed for his education, to be able to compare, interiorize and interpret information acquired in the teaching process to be able to argue their views and provide relevant judgments. In addition, tertiary education is now implemented through a range of educational forms that place specific demands on students and emphasize their personal, technical and educational competencies (Beneš, 2014). All this requires university students to be personally responsible. New students are also very often surprised by the content to the field of study they have applied for, drawing information from the internet without respecting the protection of intellectual property or without using critical thinking when collecting data.

According to experts (Zlámalová, 2008), current distance education can, in the case of inappropriately set teaching, lead to a reduction in motivation and the adult can get into a "dead end". In the field of adult education and learning, this topic can be viewed from two sub-perspectives, one arguing for, and the other against institutionalization. The current arguments against institutionalization largely coincide with Rogers' original views, as they accentuate the idea of the adult as an autonomous personality. And Nye (2004) also draws attention to the fact that the issue of facilitation is related also with the issue of power, control and decision-making in the field of interpersonal relationships. This is one of the reasons why traditional institutional authorities - schools feel threatened by the facilitation approach, and they take it often considered as controversial; that is why he tries to suppress it, consciously or unconsciously. On the contrary, arguments from the field of androdidactics emphasize higher efficiency, motivational power and greater closeness of pedagogical facilitation to life problems and situations as well as to "economic efficiency of self-determined and self-organized learning" (Beneš, 2008, p. 51). And other arguments in support of the institutionalization of adult learning point out, that the adults must also be supported and managed in their development and education. Because institutionalization "can prevent curricular deficits in the spontaneous learning" (Beneš, 2008, p. 52).

However, the success or failure of studies also affects the social climate of the study group or school. 
The positive climate in the study group induces group cohesion, which ensures favorable conditions for study. Mutuality gives students a sense of group belonging; reciprocity relaxes the study atmosphere, intensifies communication and interpersonal contact, which creates space for mutual help (Hladílek, 2009). The feeling of belonging to an individual's study group contributes to the reduction of study absence, which has a retroactive, positive impact on study success. It is obvious that the climate in the study group also reflects the overall climate of the school. From the point of view of the study success presented here, it is therefore important that a democratic climate is established in the school, for which, according to Braun, Marková and Nováčková (2014), aboveaverage relations between students and teachers are typical. In such an educational environment, teachers support and assist their students; and this has, according to the above-mentioned authors (2014), a positive impact on students' internal motivation.

And the trust built between students and the teacher, according to Long and Wood (2011), eliminates stressful situations at school, increases the effectiveness of education, and this is again reflected in academic success. However, the reasons for academic success or failure do not have to be hidden only in the abovementioned factors. To a certain extent, the pedagogue himself participates in the degree of study success or failure. It does so, for example, by choosing a suitable teaching method, its readiness for teaching, its knowledge in the subject taught, its ability not only to communicate with students but also to cooperate, to be able to explain basic aspects of the study content, offer them individual opportunities for cooperation, or even how he treats students. It follows from the above that it is the personality of the teacher, that they are his personal, professional as well as social competences that intervene in the process of education and modify it.

Of course, everything that has been said so far legitimizes the support provided to students by the teacher. However, the very issue of pedagogical support (facilitation) offers space for discussion. For example, from the point of view of behaviorism, facilitation is a form of management-empowerment. For example, the student is affected by the facial expression of the lecturer, he is influenced by changes in the behavior of his immediate educational environment in response to his success or failure in the educational process. According to behaviorists, it is not possible to mobilize a student's inner strength without having an educational effect (on the part of the teacher) or a social effect (on the part of the study team). Therefore, according to Nye (2004), this is not a purely free choice of the student. And the question of the relevance of pedagogical facilitation is also related to Knowles's (1973) concept of maturation, in which "Knowles assumes that an adult should have developed and a realistic self-concept, to respect and accept oneself, to understand one's own needs, motivations, interests, abilities and goals, to take an active attitude to life, to solve the causes of problems and to develop all the potentials of one's own personality. At the same time, he should have empathy and respect for others, understand the basic traditions, values and experiences of humanity, orient himself in his own society and participate in social and political change" (Beneš, 2014, p. 49). And Beneš (2014) in this context also considers whether an adult, autonomous individual, in whom the elements of the mentioned maturation are developed, and who is capable of selfcontrolled learning, needs facilitation at all. At the same time, however, Knowles (in: Elias and Merriam, 2005) emphasizes pedagogical facilitation, because the study facilitation of the teacher contributing to the transformation of the student, who under the influence of the activity learning is (Knowles, 1973; in: Elias and Merriam, 2005).

\section{THE CONCEPT OF PEDAGOGICAL FACILITATION}

The term facilitation is derived from the Latin word facilitar, which means to facilitate, facilitate, make something easier. The term facilitation is used in many fields and therefore is defined in a diversified way. In this paper, this concept is understood in the sense of helping and supporting adult students in the educational process. In this paper, the pedagogical facilitation is based on Knowles' (1973) concept of adult education. According to Knowles, a teacher in adult education should be more interested in the interests of students than trying to arouse their interest. And he should strive more for the true interest of the participants in the education than for what the teachers themselves think they are interested in the participants. Knowles (1973, pp. 46-47) emphasizes the facilitating role of andragogy. According to him, facilitation contributes to the personal development of the individual. This is due to the fact that the supporting approach of andragogy is based on the principles of humanistic education. It allows the student to change his self-concept when the individual develops from an originally dependent, heterogeneous personality towards a new, autonomous personality. This concept of education requires an active and internally motivated approach of an autonomous student, who chooses the goals, methods and environment of his education.

Jarvis perceives an autonomous adult set up in this way as a "homo agent - ie as an active social actor” (Jarvis, in: Bartoňková, Šimek, 2002, p. 180), who is able to intentionally develop and realize their own potential. According to Kosová (2013), the subject-subject scheme of education is set in education conceived in this way, where the teacher is the subject of the management of the educational process and the adult student is the subject of learning and self-development. Jarvis (1985, p. 27) called this 
educational approach "the education of equals". The aim of pedagogical facilitation is then to support the personal change of students, to which the fact that facilitation facilitates their learning contributes.

The emphasis on the ability to learn is justified by the fact that, according to Motschnig and Nykl (2011, p. 113), they have no knowledge in today's hectic, rapidly changing and evolving world. And knowledge permanent validity and a certain certainty is offered only to the process of acquiring knowledge, the process of learning or education. Great importance in the process of self-directed learning and the mentioned personal development then play the life experience of the individual, which are the source of his learning and create a basic network of his preconcepts, on which it is possible to build a quantitatively and qualitatively higher level of knowledge. With regard to the above, one of the declared goals of the facilitation is the intellectual independence of students, their greater creativity and selfconfidence, which, however, can be achieved, in addition to the mentioned pedagogical facilitation, also through self-criticism and self-esteem (Bertrand, 1998).

Knowles (1975) bases his concept of adult education on two basic premises. In the first of these, the author says that adults are increasingly willing to learn throughout their lives, because in the process of learning they focus more on coping with problems of everyday practice and newly acquired study knowledge helps them better fulfill and realize their social roles, predict possible own social and professional life and participate in the life of society. In this context, Motschnig and Nykl (2011) even state that man is possible considered educated only if he learned to learn and adapt quickly changing world. However, these authors immediately (2011) add that the issue of education is very debatable, because many adults do not know how to learn and do not even want to learn, also because that they are afraid of their possible academic failure. According to the authors, one of the goals of pedagogical facilitation should be to support study competence. Because only man, who can learn himself, can adapt to rapidly changing world. And for it, it is necessary to learn, constantly supplement and update previously acquired knowledge, skills and competencies. According to Motschnig and Nykl (2011, p. 114), research in adult education has shown that "learning has the most lasting effect when in a human-centered climate it includes three levels of development intellect, (social) skills and the basis of personality".

Rogers in his 1998 publication confirms the positive effect of facilitation, focused to an adult in the process of education. According to Rogers and Freiberg (1998), facilitation leads to a clear psychological growth of students, especially in that pedagogical facilitation allows the adult student to accept himself and his feelings. Facilitation provides students with greater self-confidence, helps them determine or direct their life direction, gives them tools for greater understanding of themselves and other people. Facilitation allows the student a more flexible perception of their feelings and the feelings of their surroundings; it helps him to set realistic educational and life goals. According to Rogers and Freiberg (1998), the facilitation of openness to reality teaches, and thanks to all the above factors, there is a better self-concept in supported individuals, which is reflected in a higher agreement of real reality with the ideal self-image. In order to make pedagogical facilitation in formal adult education as effective as possible, Rogers and Freiberg (1998) recommend that the educational group be divided into smaller functional units, with about four participants who motivate each other and learn to work together to find answers to questions. they consider themselves. Although these authors admit that by accepting this form of facilitation, adult students will not gain such a body of knowledge and as many objective facts as in face-to-face teaching, they will be acquainted with the learning process and self-assessment as a means of taking responsibility for their own learning process. "As a result, students learn to take responsibility for themselves and their development" (Rogers and Freiberg, 1998, p. 234)

\section{PERSONAL CONDITIONS OF FACILITATION}

Facilitators share responsibility for the learning process, provide students with relevant learning resources (from professional materials and generalized experience), and help to ensure that learning takes place in a facilitative atmosphere. According to Rogers and Freiberg (1998, pp. 225-226), in order for the personal conditions of pedagogical facilitation to be fulfilled, it is necessary that the ideal facilitation strives to meet at least the following three conditions:

1 / Pedagogical congruence (authenticity, authenticity) allows the teacher openly and realistically experience his current feelings and attitudes and thus contributes to his balance. According to Motschnig and Nykl (2011), congruence consists of two parts, which are the concordance between inner experience and a conscious approach to it and the ability to communicate one's inner experience to other people.

2 / The concept of empathic understanding includes the art of the teacher to listen to students and effort about understanding and perceiving the meanings and feelings of the other person, both feelings, conscious and and the unconscious (Motschnig and Nykl, 2011).

3 / And the term acceptance can then be understood as an unconditionally positive acceptance of students, interest in them or trust in them. Acceptance conceived in this way is based on rewarding students as they are. However, this acceptance or also a positive acceptance can be felt 
by the teacher towards his students even without him, without having to unconditionally agree with their personal opinions or with their actions. It is therefore not about evaluation or reaction, but about the perception of students with all their needs, aspirations, possibilities and limitations.

At the end of this part of the paper, it is appropriate to state that the general goal of such a perceived facilitation is not to unconditionally fulfill all three of the above conditions, but [figuratively] to achieve the greatest possible space to overlap them. From this, an appropriate degree of student facilitation can be derived (Motschnig and Nykl, 2001, p. 79).

\section{FACILITATION AS PART}

\section{OF AN INTERPERSONAL RELATIONSHIP}

As early as 1977, Patterson pointed out that teaching is a personal interpersonal relationship built on a teacher-student dyad. Even today, the emphasis is on student-oriented teaching. In this modern pedocentric conception of education, the pedagogue is no longer a decisive element of the process of education and learning (Beneš, 2008, p. 109). This educational approach thus places increased responsibility for the educational process on both actors of the mentioned educational dyad; that is, both for the adult student and for the teacher himself, but this also brings with it certain difficulties. For example, Houssaye (1992, in Bertrand, 1998, p. 224) pointed out that the humanistic theories on which the concept of education is based reject the idea of an external goal and trust in the power of human nature, but that this radical emphasis on the principle of individual freedom in the educational process can ultimately lead to ineffective non-interference in the educational process. And thanks to this, the student can face "motivational problems and disorientation" (Beneš, 2008, p. 50). And Nye (2004) also points out that it is extremely difficult, especially for beginning students, to understand and adequately express their real educational feelings and needs, which can lead to a reduction in the effectiveness of education.

From the teacher's point of view, the role of facilitator is extremely structured and complex. Not only does facilitation place demands on his personal and emotional components (such as the aforementioned congruence, ability to empathically understand and accept), but also on his cognitive component, where the concept of facilitation requires its deep and broad professional portfolio to educate educators, impart to them the knowledge, skills, abilities and experience. And the process of education is also based on the docility of the teacher, an integral part of which is his readiness to learn permanently and therefore for life. It is obvious that in order for the above-mentioned pro-educational, facilitative atmosphere to be able to stimulate the personal development of an adult student in the direction of his self-actualization, it is necessary that in the educational dyad, the teacher and the student set a high degree of will, reciprocity and initiative. However, according to some experts (Drapela, 2008), very often these aspects of a functional interpersonal relationship are saturated only by teachers. Perhaps that is why Drapela (2008, p. 125) considers so-called educational optimism to be exaggerated, naive and unrealistic.

\section{EXPLORATORY INVESTIGATION}

As part of the preparation of this paper, its author conducted a survey, the aim of which was to look at some aspects of university studies from the perspective of the students of the two bachelor's degree programs.

\section{SURVEY RESPONDENTS}

The respondents to the survey were $42(\mathrm{~N}=$ 42) students from two bachelor's degree programs. The first group of respondents consisted of $25(\mathrm{~N}=$ 25) full-time students of pedagogy, future teachers at secondary schools with an average age of 21.5 years. The second group of respondents is $17(\mathrm{~N}=17)$ students of combined andragogy, with an average age of 36.5 years.

\section{DATA}

The collection of survey data was carried out by the method of questioning. The author of this paper, on line, focused on a focus group with fulltime students. In the qualitative exploration strategy, the focus group method is understood as a focus group (Švaříček, Šedová, 2007), which relies on the accumulation of stimuli in a conversation with a group of people, and which uses the interaction of group members during the discussion (so-called snowball effect). It is an interactive concept, where individual participants can comment on the opinions of others and at the same time the joint interaction gives them a safe space to express their own opinions and opinions. Distance learning students were asked to answer questions about their studies freely. Because the explorer's intention was to get the most natural answers from the respondents, therefore, the written answers thus obtained were not translated into the form of closed questions and were not quantified. But in accordance with Loučková (2001) they were left with their original narrative form. And a numerical scale was chosen to collect exploratory data on the question of the required degree of facilitation.

The answers of the respondents were then processed in the form of a thematic analysis. Braun and Clarke (2006, p. 79) describe thematic analysis as a "method of identification, analysis and referencing to patterns (topics) in the data". According to Braun and Clark (2006), thematic analysis can be used in two ways. The first method 
presents theory-independent procedures (inductive thematic analysis), where research questions appear only during the analysis itself. The second way belongs to the theoretical approach to thematic analysis. In this approach, research questions are set in advance, based on the study of theory related to a given educational area. In this second approach, the literature is studied first. This helps the explorer not to overlook important aspects of the data being examined when analyzing the data (Braun and Clarke, 2006). The analysis of the respondents' answers was performed in the steps shown in the following table:

Table 1

Thematic data analysis

\begin{tabular}{|l|l|l|}
\hline $\begin{array}{l}\text { Partial stages } \\
\text { of analysis }\end{array}$ & Content of partial phases of thematic analysis \\
\hline 1 & $\begin{array}{l}\text { Acquaintance } \\
\text { survey. data }\end{array}$ & $\begin{array}{l}\text { Getting to know the data involved reading the entire data set. The explorer actively approached the data, } \\
\text { looking for meanings, formulas, creating the first codes. }\end{array}$ \\
\hline 2 & $\begin{array}{l}\text { Generating } \\
\text { of primary codes }\end{array}$ & $\begin{array}{l}\text { Then, an initial list of interesting features, specific codes and data was compiled. The researcher looked } \\
\text { for recurring patterns in the respondents' answers. }\end{array}$ \\
\hline 3 & Search for topics & $\begin{array}{l}\text { In this phase of the analysis, the data were compared and the codes were subsequently sorted into potential } \\
\text { topics. Codes between topics must not overlap. The explorer must decide where to place which code. } \\
\text { Therefore, the explorer recorded the survey data in tables and mental maps. }\end{array}$ \\
\hline 4 & $\begin{array}{l}\text { Revision } \\
\text { accuracy of topics }\end{array}$ & $\begin{array}{l}\text { Clarifying the boundaries between the topics, the whole file is re-read so as not to omit any important } \\
\text { aspect. }\end{array}$ \\
\hline 5 & $\begin{array}{l}\text { Defining, } \\
\text { naming topics }\end{array}$ & $\begin{array}{l}\text { In this phase of the analysis, the individual topics were defined. The explorer considered each topic } \\
\text { and their interconnections. }\end{array}$ \\
\hline 6 & Final analysis & Based on the choice of final topics, a final analysis was performed. \\
\hline \multicolumn{2}{|c|}{ Source: own } & \multicolumn{2}{l}{}
\end{tabular}

\section{INTERPRETATION OF SURVEY DATA}

With regard to the spatial subsidy of the given contribution, six topics will be presented here.

\section{Causes of failure of previous studies}

The own survey data showed that in both mentioned respondent groups there are students who are studying the second or third bachelor's field, because their previous studies ended in failure. Students justified their initial study failure by a number of reasons, most often by choosing an inappropriate field of study. One of the students stated: I did not enjoy my studies, I did not need to continue my studies, reading professional literature seemed demanding and uninteresting to me. I often experienced feelings of anxiety during my studies. Another full-time student said that her academic failure was caused by her social situation: I need to take care of myself financially, so I did not have the opportunity to devote as much time as was needed for the field. Students of the combined form of andragogy study then associated their initial academic failure with the fact that they had trouble combining their studies with employment and with caring for their family.

Students' answers to the question of the cause of their initial academic failure were very diversified, which only confirms the great diversity of the structure of current university students. However, it is only possible to speculate how large the representation of these students is, because not all respondents answered the question of which bachelor's study they are. However, experts (Pikálková, Vojtěch and Kleňha, 2014) state in connection with the faculties of education that in the first two years of the bachelor's field of pedagogy, teaching and social work, 23 percent of students drop out of university. These authors state that the study failure rate increased by 4 percent between 2006 and 2012, which is confirmed by the data presented in the theoretical part of this paper. However, the report of the Ministry of Education, Youth and Sports from 2020 shows that in the academic year 2014/2015, the decline in academic failure stopped, and that so far the decline has stagnated.

Communication in the pedagogue-student dyad

One of the students stated in defense of her initial academic failure something that the author of this article perceives as a memento, which is closely related to the outlined topic. The student wrote: The feeling that I was only responsible for the study number at school, that I did not find the courage to ask the teacher for help with explaining the subject matter... Experts (Gavora, 2005) perceive communication in the mentioned educational dyadic relation as a basic means of realization of upbringing and education through verbal and nonverbal expressions of pedagogue and student. In the above case, it is therefore necessary to ask about personal, communication and the diagnostic skills of the teacher. Švaříček, Šed'ová and Šalamounová (2005) talk about the fact that the subject-subject scheme in adult education calls for the pedagogue to withdraw from his dominance and to be a facilitator of learning and an educational partner for students. If that were the case, the situation would probably not have happened at all. And this situation is very closely related to the erudition of the teacher, which includes 
not only the communication but also the diagnostic competencies of the teacher,

\section{Another exploratory topic was External Pressure to Study.}

The answers of some respondents showed that they are not studying the field in which they would be interested. In their answers, they justified this situation by saying that they went to university because that their parents wanted it because or because studying at college is socially desirable and fashionable. Respondents also stated that so far it is better for them to have the status of a student than the status of an unemployed or a worker. And one of the students said in his answer "that he wants to have it" easy "at home and as long as he studies, he has peace from his parents at home".

According to Hrubá (2017), the fact that parents who have not fulfilled their own desire - aspiration for education or those parents who are aware of the importance of education have high educational expectations from their descendants. Research (Švarcová, Gabrhel 2012) confirms the correlation between the level of education attained by parents and their aspirations of the study their children; the higher the cultural capital of the parents (their education), the greater the pressure on their children to continue their studies. These parents perceive education as a means of ensuring the dominant position of their children in society. However, Katrňák (2004) points out that people who do not desire education and who have only listened their parents do not have the necessary internal motivation to pursue school and are leaving the education system early, because they cannot pursue other branches of education or simply they do not want to do so due to poor academic results to try it.

\section{The form of the pedagogical facilitation}

When asked what the form of pedagogical facilitation should take the form, the full-time students answered, that the facilitation should be set so that the teacher is interested about student. That the teacher shares and solves the student's problems, not the other way around. Students also require teachers to support their study self-confidence, in the form of praise. Although the students' answers are very diversified, they all place great emphasis on a facilitative educational style, the basic premise of which is that the teacher is in the background of teaching and offers students a safe space for their self-expression and selfreflection, he support their self-actualization and selfunderstanding. Facilitating teaching style emphasizes the views of students, taking into account their previous experience (Fenstermacher, Soltis, 2008). According to Rogers (1998), facilitation consists primarily in supporting the learning efforts of the students themselves. And the educator should not impose anything on them or manipulate them in any way, even in good faith, that it would be so-called for their good. Thus, students basically reflect the opinion of J. Holt (in: Kovarík, 2018) that it is always the first and most important task of every teacher to help the student become independent of the teacher, to learn to be a teacher to himself. It follows that the teacher will teach his student the right technique for how to develop, recommend quality resources and help him with orientation. "A real teacher must always strive to get himself out of the game". At the same time, however, the students' answers showed that the demands on the form of pedagogical facilitation change during their studies. Full-time students required teachers to have a more partnership-based approach and support for the psychosocial aspects of education.

Combined study students emphasized the professional and didactic competencies of teachers and demanded support in finding relevant resources and assistance in grasping educational topics. This form of pedagogical facilitation places great demands on the erudition of the teacher, on his professional and character qualities, on his preparation and multilateral development. The concept of erudition is understood in this paper as a broad education that exceeds the current level of academics. According to Střelec (2011), pedagogical erudition is an integral and integral part of education and consists of practical pedagogical, didactic and methodological skills and habits enabling the pedagogue to transfer his knowledge into immediate educational practice. This transfer of knowledge is ensured not only by the communication skills that the teacher applies in interaction with the student, but also by the rhetorical skills that enhance the culture of educational activity.

\section{The degree of facilitation required}

To express the required degree of pedagogical facilitation, a numerical scale was chosen, when students answer were on a scale of 1-10, with the number 10 representing the highest possible level of required pedagogical support. It is certainly not without interest that the level of required pedagogical facilitation differed between the two groups of respondents mentioned. While younger full-time students set the required facilitation rate at 5 , combined form students demanded the required facilitation rate at 7.5. The mentioned difference in the required degree of pedagogical facilitation may be due to the different age of students in both respondent groups. Hogan et al. (2010) or Nonis et al. (2005) speaks of a greater study chance of the students with personal maturity for their study success. Their probability of study success is increased by such personality characteristics as diligence, perseverance, conscientiousness, independence, consideration and independence. And according to Matošková and Potočková (2016, p. 31) tacit knowledge also contributes to academic success. These can be roughly identified with human capital 
and partly with social capital. An integral part of them are the individual experiences of students, which also include intangible factors such as personal beliefs, insights and value systems. This knowledge is difficult to express, so it must be given into a narrative form. And this presupposes a certain level of communicator and his ability to verbalize his thoughts.

\section{Support of internal motivation}

More than a third of full-time students declared that the goal of pedagogical facilitation should be to support their internal motivation. Following the above, the author of this article asks why people go to university when it is not supported by their inner motivation or interest. Partial answer the issue has already been discussed on the subject of external pressure on education. And another answer was given by Šafránková and Šikýr (2017). They made research with 431 full-time and part-time bachelor's degree students offered further explanation. $62 \%$ of respondents - students declared that they study only to obtain a university degree. The question of their education is not important for them, because according to the above respondents, everything you needed can be found on the Internet today. And according to $71 \%$ of students, their low internal motivation is related to the low level of teaching. According to the mentioned authors (2017), the high level of potential dissatisfaction of students related with the level of teaching. Students share their opinion via social networks, thanks to which even those who did not even have such an opinion lean towards the opinion. Respondents to the survey also declared that they did not attend lectures and seminars in order to learn something new, but mainly in order to write a test or pass an exam. Within the focus group, students also declared that the number of students at universities devalues the value of university studies, which results in their lower chance of quality employment in the labor market. One of the students stated with some contempt: Maria Theresa ordered compulsory schooling. During the First Republic, university studies were a sign of social prestige. Today, however, 300,000 of us are studying. And before we finish graduating, everyone will be studying at the university again. So why try. These answers were in line with the answers of the respondents of the Šafránková and Šikýr survey (2017), according to which $74 \%$ of students stated that they rate their chances on the labor market as average or below average. These students are afraid of strong competition.

The data given by the author of this paper are not only seen as a challenge for educational institutions, but also for the pedagogical facilitation itself, as university graduates are expected to that they will be prepared for continuous lifelong learning and for the continuous development of the necessary professional knowledge, skills and competences, as well as the appropriate work and social habits needed for successful employment and private life. However, it is relatively difficult to meet these requirements without internal motivation.

\section{OTHER POSSIBLE FOCUS OF THE SURVEY}

It was stated above that the mentioned pedagogical facilitation places high demands on the whole range of competencies as well as on the erudition of the pedagogue. Therefore, the author of this paper would like to address university teachers and would like to explore whether they are interested in providing facilitation to students, or if they have an idea of its form and scope, or where teachers see the limits of the educational approach.

\section{REFERENCES}

1. Bartonkova, H., Simek, D. (2002). Andragogika. Olomouc: UPOL, 65 pp. ISBN 80-244-0394-3.

2. Beneš, M. (2008). Andragogy. Prague: Grada Publishing, 135 pp. ISBN 978-80- 247-2580-2.

3. Beneš, M. (2014). Andragogy. 2nd ed. Prague: Grada Publishing. 176p p. ISBN 978-80-247-4824-5.

4. Bertrand, Y. (1998). Contemporary Theories of Education. Prague: Portal, 247 pp. ISBN 80-7178-216-5. 5. Braun, R., Marková, D., Nováčková, J. (2014). Practicum of School Psychology. Prague: Portal, 214 pp. ISBN 9788026201762.

6. Braun, V., Clarke, V. (2006). Using Thematic Analysis in Psychology. Qualitative Research in Psychology, 3 (2), pp. 77-101. ISSN 1478-0887.

http://eprints.uwe.ac.uk/ 11735

7. Long-term Plan of Educational and Scientific, Research, Development, Artistic and Other Creative Activities for the Area of Universities (Long-term plan of the Ministry). (2001).

8. Drapela, V. J. (2008). Overview of Personality Theories. Prague: Portal, 175 pp. ISBN 978-80-7367-505-9.

9. Ellias, J. L., Merriam, S. B. (2005). Philosophical Foundations of Adult Education. Malabar: Krieger Publishing Company, 286 pp. ISBN 978-1575242545.

10. Fenstermacher, G. D., Soltis, J. F. (2008). Teaching Styles of Teachers. Prague: Portal, 124 pp. ISBN 9788073674717.

11. Gavora, P. (2005). Teacher and Pupils in Communication. Brno: Paido, 165 pp. ISBN 80-731-5104-9. 12. Hladílek, M. (2009). Chapters from General Didactics and Didactics of Adult Education. Prague: UJAK, 186 pp. ISBN 978-80-86723-75-4. 
13. Hogan, M. J. et al. (2010). Academic Success in Adolescence: Relationships among verbal IQ, social support and emotional intelligence. Australian Journal of Psychology, 62 (1), 30-41.

14. Hrubá, L. (2017). Social Determinants of High Educational Expectations of Parents. Prague: Sociology, 49, No. 5, 0049-1225.

15. Jarvis, P. (1985). The Sociology of Adult and Continuing Education. 2nd edition. London/New York: 278 pp. Routledge. ISBN 0-7099-1439-3.

16. Katrňák, T. (2004). Doomed to Manual Work: educational reproduction in a working class family. Prague: Sociologické nakladatelství, 290 pp. ISBN 80-86429-29-6.

17. Knowles, M. S. (1973). The Adult Learner: a neglected species. Houston: Gulf Pub, 308 pp. ISBN 0-87201-005-8.

18. Knowles, M. S. (1975). Self-directed Learning: A Guide for Learners and Teachers. Cambridge: Englewood Cliffs: Prentice Hall, 135 pp. ISBN 0695811169.

19. Kohoutek, R. (2009). Psychology of School Success and Failure. Psychology in Theory and Practice. http://rudolfkohoutek.blog.cz/0911/psychologie-skolni-uspesnosti-aneu spesnosti

20. Kosová, B. (2013). Philosophical and Global Context of Education. Banská Bystrica: PF UMB, 173 pp. ISBN 978-80-557-0434-0.

21. Kovaŕík, P. (2018). How is the Role of the Teacher Changing in Today's World? Teacher as a leader three times different. Teacher's sheets, 4/2018.

22. Long, M., Wood, C. (2011). The Psychology of Education. UK: Oxford, 438 pp. ISBN 978-0-41548690-3.

23. Loučková, I. (2001). Towards Integrated Strategies Not Only in Research in Social Work. Sociologický časopis / Czech Sociological Review, 37 (3): 275-296 pp. 313-328, ISSN 0038-0288 (Print).

24. Matošková, J., Potočková, G. (2016). The Life of a Successful Student at University. Psychology for Practice, 3-4, LI, pp. 21-34. ISSN 1803-8670.

25. Motsching, R., Nykl, L. (2011). Human-centered Communication: Understanding Oneself and Others. Prague: Grada Publishing, 176 pp. ISBN 978-80-247- 3612-9.

26. Nonis, S. A., Hudson, G. I., Philhours, M. J., Teng, J. K. (2005). Changes in College Student Composition and Implications for Marketing Education: revisiting predictors of academic success. Journal of Business Research, 58 (3), 321-329.

27. Nye, R. D. (2004). Three Psychologies: The Concepts of Freud, Skinner, and Rogers. Bratislava: Ikar, 168 pp. ISBN 80-551-0819-6.

28. Patterson, C. H. (1977). Carl Rogers and Humanistic Education. In: Cecil Holden PATTER SON. Foundations for a theory of instruction and educational psychology [online]. Harper \& Row. ISBN 9780060450571.

http://www.sageofasheville.com/pub_downloads/CARLROGERS ANDHUMANISTICEDUCATION.pdf. 29. Pikálková, S., Vojtěch, J., Kleňha, D. (2014). Success of High School Graduates in University Studies, Early School Leaving. Prague: NÚV, 52 p.

30. Rogers, C. R., Freiberg, J. (1998). Freedom to Learn. Blue: Person, 429 pp. ISBN 80-967980-0-6.

31. Study Failure of University Students. (2020). Paper presented at the conference Days of Educational Activities of Universities, Prague: National Technical Library.

32. Stiburek, Š., Vlk, A. (2017). Study Failure at Universities. Prague: ELEPHANT, 154 pp. ISBN 978-807419-248-7.

33. Střelec, S. (2011). University Teacher's Pedagogical Competence and Social and Health Aspects of Teaching. In SZERLAG, A. (ed.) Academic Teacher Facing the Educational Challenges of the 21st Century. 1st ed. Wroclaw: Akademia Medyczna Wroclaw - Oficyna Wydawnicza ATUT, pp. 217-228, 12 pp. ISBN 978-83-7432-753-4.

34. Study success at Czech universities in 2018. Report of the Ministry of Education. Prague: Ministry of Education. 2020, 5 pp.

https://www.msmt.cz/uploads/odbor_30/TF/Analyticke_materialy / Studijni_uspesnost_na_ceskych_ vysokych_skolach_v_roce_2018.pdf.

35. Šafránková, J. Šikýřr, M. (2017). Motivation to Study and Career of Students and Graduates of the University of Regional Development. The result of the survey, Prague: AMBIS, 9 p.

36. Šed’ová, K., Novotný, P. (2006). Educational Needs in Relation to Participation in Adult Education. Pedagogy, Prague: PdF UK, Vol. 2, pp. 140-151.

37. Šedová, K., Švaříček, R., Šalamounová, Z. (2012). Communication in the School Classroom. Prague: Portal, 293 pp. ISBN 978-802-6200-857.

38. Švarcová, J., Gabrhel, V. (2012). Educational Aspirations and Educational Mobility of High School Students in the Czech Republic. E + M Economics and Management, 2, pp. 4-11.

39. Veteška, J. (2016). Overview of Andragogy. Prague: Portal, 320 pp. ISBN 978-80-262-1026-9.

40. Zlámalová, H. (2008). Distance Education and eLearning. Prague: UJAK, 144 pp. ISBN 978-80-8672356-3. 


\section{Hana Vavříková, \\ ПЕДАГОГІЧНА ФАСИЛІТАЦІЯ З ТОЧКИ ЗОРУ СТУДЕНТІВ}

Професійна громадськість тривалий час обговорює причини того, чому більше 2/5 чеських студентів, які навчаються на бакалаврських програмах, не мають успіху у своєму першому навчанні. у статті викладаються можливі причини цього явища, згадуються часткові фактори, що впливають на академічний успіх чи невдачу, зазначається вплив на життя людей та суспільства. І останнє, але не менш важливе: ия стаття стосується педагогічної фасилітації, тобто міжособистісної діяльності, яка могла б усунути деякі причини неуспішності в навчанні (низька внутрішня мотивація, розчарування) і створити сприятливе освітнє середовище, а отже, збільшити успішність навчання студентів університету. У рамках підготовки чієї статті ї̈ автор провів опитування, метою якого було розглянути часткові аспекти неуспішності навчання та педагогічного сприяння з точки зору студентів двох форм (денної, комбінованої) бакалаврських програм навчання на педагогічному факультеті Остравського університету.

Ключові слова: причини невдач, неуспішність у навчанні, низька мотивачія, педагогічна фасилітація.

Стаття надійшла до редакції 10.12.2020 p.

Прийнято до друку 14.12.2020 p. 